\title{
Las Heras: An Imagined Future. Stories of an Emerging World
}

NARRATION

\section{Will Alsop}

ABSTRACT - The estate Las Heras lies close to Girona in Spain. I was taken there by my client, in the form of a mystery tour. We arrived at a large house within 350 hectares. I felt instant affinity to this place before leaving the car. I asked my client: "Why did you buy this?" He answered: "...that is YOUR project - to tell ME!"

The land exuded a sense of place which appeared irrational. Time and neglect had taken its toll on the main house and work began to repair the building.

The estate has a long and tumultuous history; the past informs the present and creates context for the experience of the place. The future required a possible description. A narrative (novella) was an indulgence that allowed exploration of what might happen in the formation of the place. The book exists as a plan, a gazetteer volume of information, and a cookbook, intended to stimulate and encourage.

The emerging project's starting point is as an educational resource for anyone; particularly for architectural and art institutions.

Keywords: narrative, memory, place, design education, Las Heras

The house and terrain are beautiful. I had noticed that whenever I took someone to visit, they each loved it. There is something about this place that allows people to succumb to some natural sense of being without question. It was perfect and yet the question arises, what to do with this empty place? I am an architect and for some time it has worried me that architects, with 
one or two exceptions, are expected, or expect themselves to do something architectural. Hence the urge to do nothing was as strong as ever. This Arcadian paradise should not repeat history of Eden. The sin of improvement should not be committed here, as I increasingly believe in other places. The world lies at the mercy of the architectural industry and architects, amongst others. Architecture offices are often judged today on the quantity of their output. Offices are more global and many grow by acquisition. This is a business and has nothing to do with architecture. It is a world led by accountants not art. Add to this phenomena other words like "placemakers," "urban designers," "space analysts," etc. and the pressure is to make "stuff," "alter things" and destroy. How many sins are committed by the single word "regeneration"? How do you breathe life back into an empty house? The original part of the home is 1,000 years old and right up to the beginning of the twentieth century it was added to and adapted. A lady of the original family lived in the home up until 2007 at which point she decided through age and remoteness that she should sell and move out. She moved abandoning the estate to fend for itself and swearing that she would never return. The home has stories...

\section{"WITNESS TO HISTORY" by J.J. Caballero}

When the first stones were being laid to build the walls of the Masía de Las Heras, a powerful culture was developing a couple of hundred miles to the North: that of the Cathars, with ambitions to spread across Europe. Another couple of hundred miles to the South, roughly along the natural borderline created by the River Ebro, the land was held by the Muslims. And just a short distance from the masía, on this side of the Pyrenees, the counties created by Charlemagne were becoming more consolidated. They were to give rise to what was known as the Marca Hispánica; the buffer zone between the Muslim and Frankish empires.

\section{The birth of the masias}

Las Heras formed part of what is known as Catalunya Vella, or Old Catalonia: the land that lies to the East of the Llobregat river. It was here that a type of building known as a masía was developed, featuring certain characteristics of which Las Heras is a prime example. One only has to look at its south-facing semi-circular arched doorway with its well-defined, perfectly fitting voussoirs that have stood the test of time for hundreds of years.

The main façade was always south-facing, to maximise the light and warmth of the sun on its journey from East to West. For the same reason, particularly in the Empordà region and other areas close to the Pyrenees, the doors and windows on the Northern facade were small, to avoid drafts created by the strong, chilly Tramontana winds that come down from the mountains. 


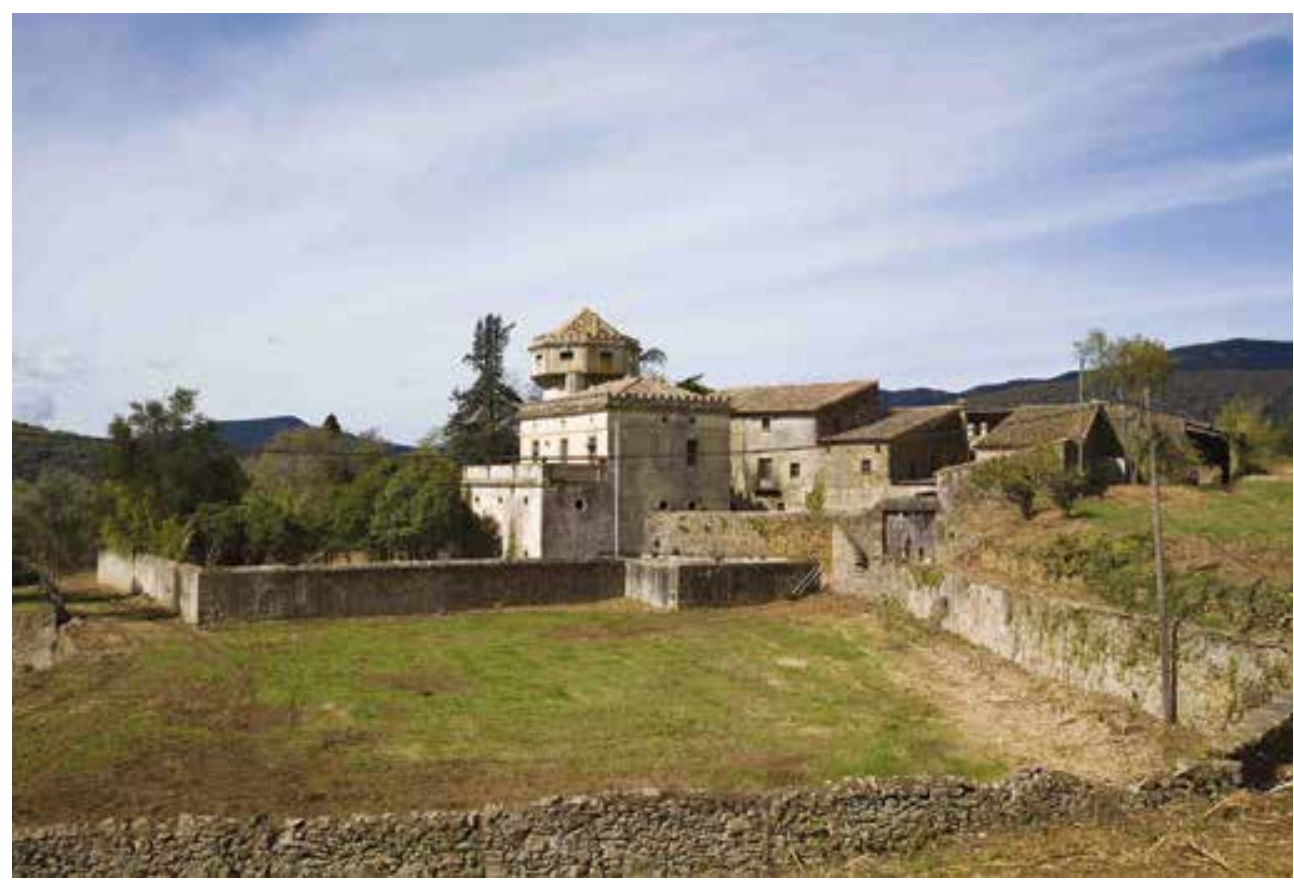

Fig. 1

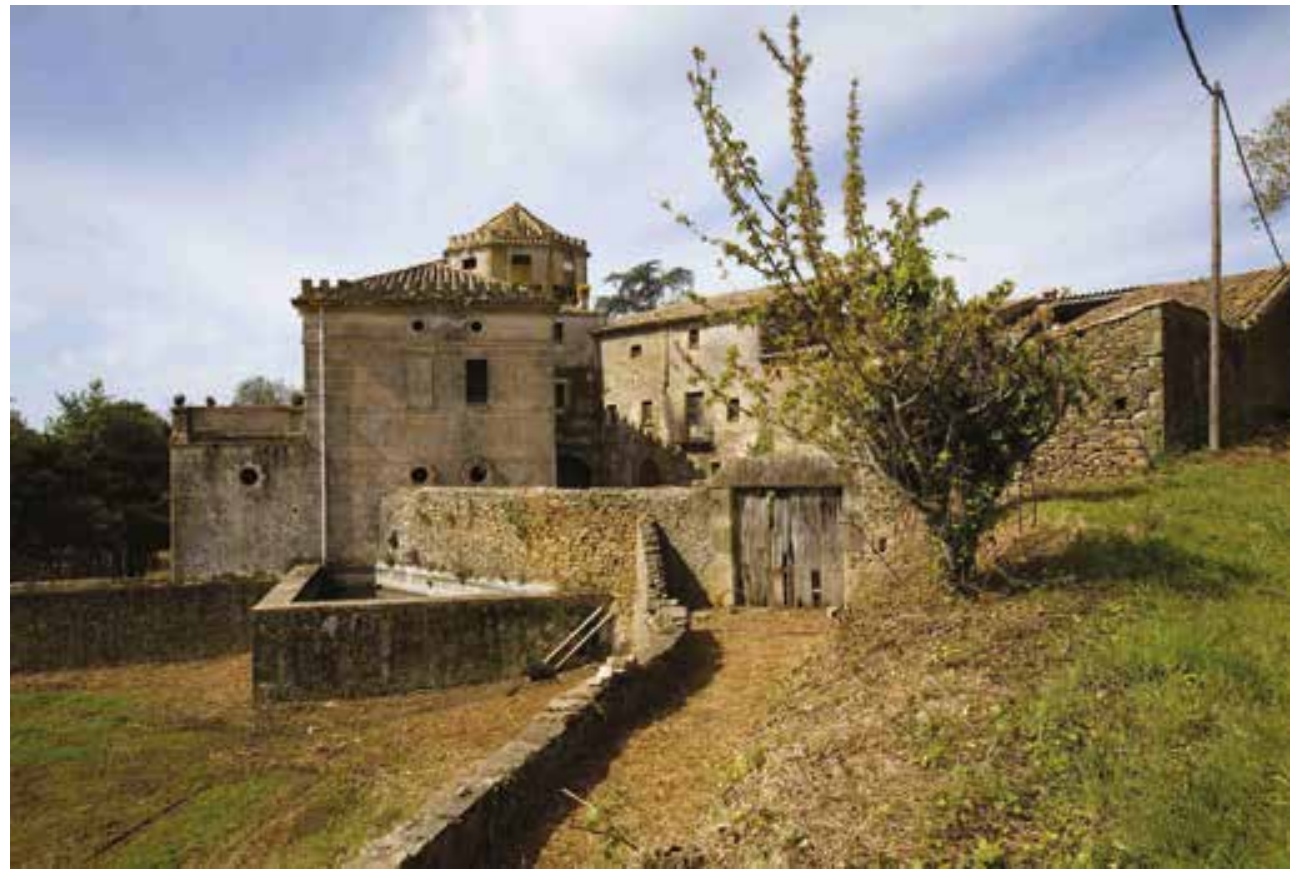

Fig. 2

Figures 1 and 2. Las Heras, views of the complex.

These farmhouses were traditionally austere in appearance. Local stone was used and it was only carved when used around windows and occasionally, as cornerstones. Las Heras is mostly built from sandstone, a very hardy material, although it can be subject to wear and tear due to the effect of rain, cold and wind.

Indoors, the floor was paved with stone, but the size of the original slabs inside Las Heras is quite extraordinary. In very few places can one see paving stones of this size, some of them one metre 


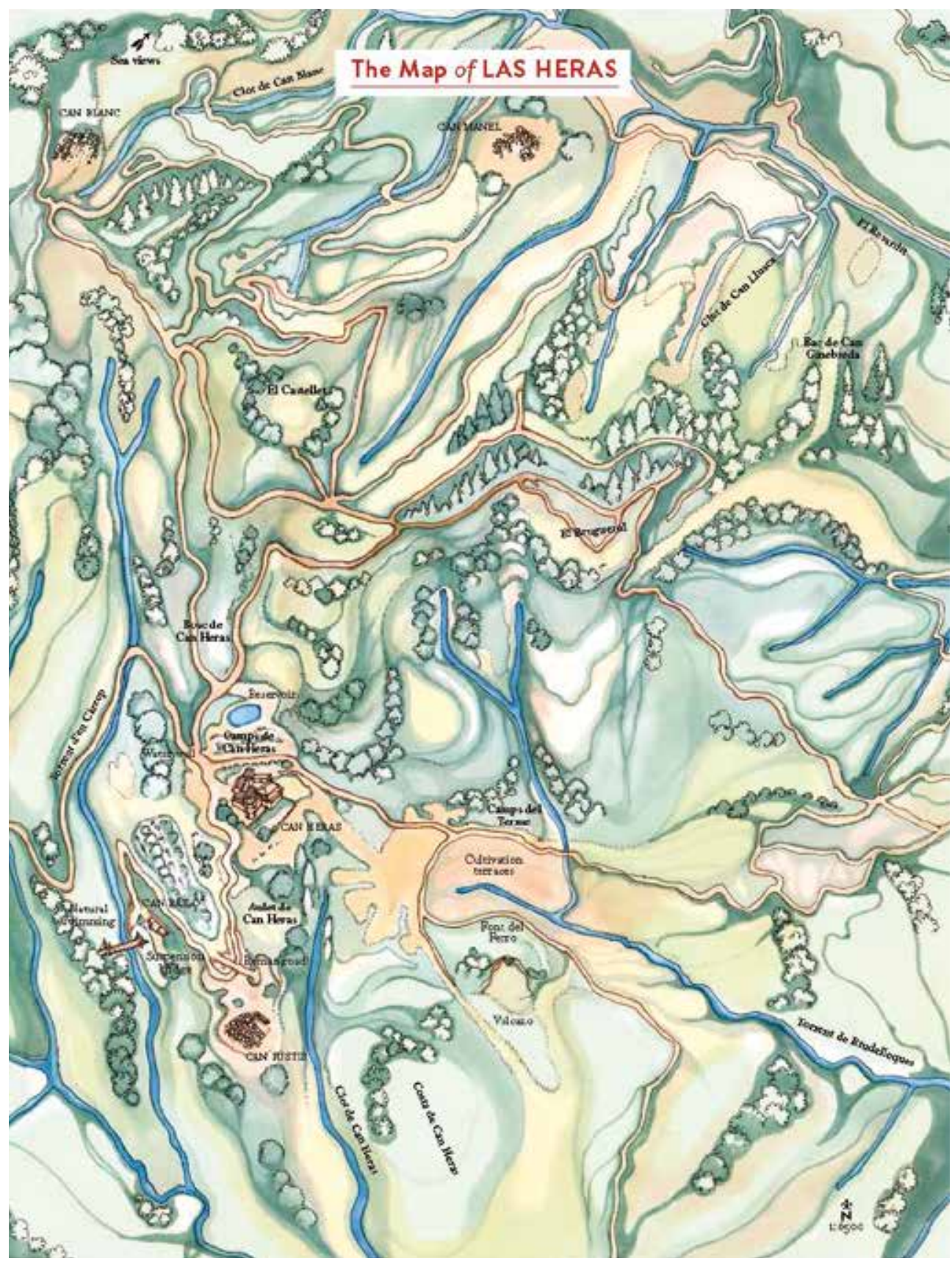

Figure 3. Las Heras, map of the estate.

long. This is one of the distinct features of the masia, which, in other respects, shares most of its other elements with other typical Catalan farmhouses.

And one of these elements is the kitchen: the focus of daily life during the cold winter months. Everything revolved around the hearth, where the fire would be permanently lit and used both for cooking and for heating the house. At Las Heras, the enormous fireplace even played a role in an event featuring one of the most infamous bandits of the nineteenth century: an outlaw who went 
by the name of Boquica. During a raid on the house, he hung the owner over the fire to force him to reveal the whereabouts of the family jewels and other valuable items. Miquel Heras died twelve days later as a result of the serious burns he suffered.

\section{The last golden age}

The twentieth century saw Can Heras's final moments of glory, but also times of great sadness: the Spanish Civil War and the decline of the farmhouses and their lands. In the early years of the century, the roaring twenties, big parties were organized at the house. The guests would arrive in Canet in their impressive cars and elegant attire, but from there they had no option but to walk the rest of the way to the house. Sometimes, very finely-dressed women would arrive alone. In the surrounding villages, memories remain of those parties... and those ladies.

\section{Childhood memories}

María Heras's childhood memories are still very much alive. They are the memories of a time when "everything seemed wonderful
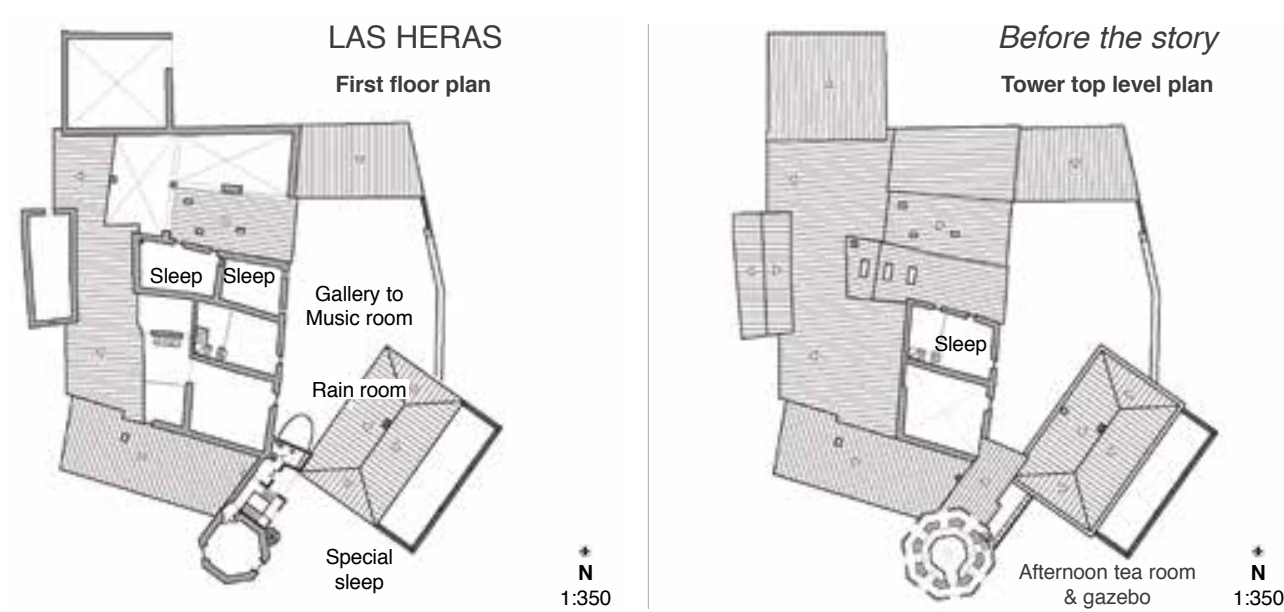

Figure 4. Las Heras, plans. ㄷ aLLAlsop Research.

to me". "We'd wake up with the sun and go out, barefoot and in our nightgowns, to pick fresh figs. Yes! In our nightgowns! The whole estate was ours, you see. We'd walk four kilometres from one end to the other. Sometimes we'd go and listen to a man at Can Brugada who used to tell us stories about Cuba. He'd spent a few years there. They used to call him "the godfather of Can Brugada." His surname was Noguer. He wore the traditional Catalan hat and red sash around his waist. He had about twenty sheep. "Ship", he'd say. 


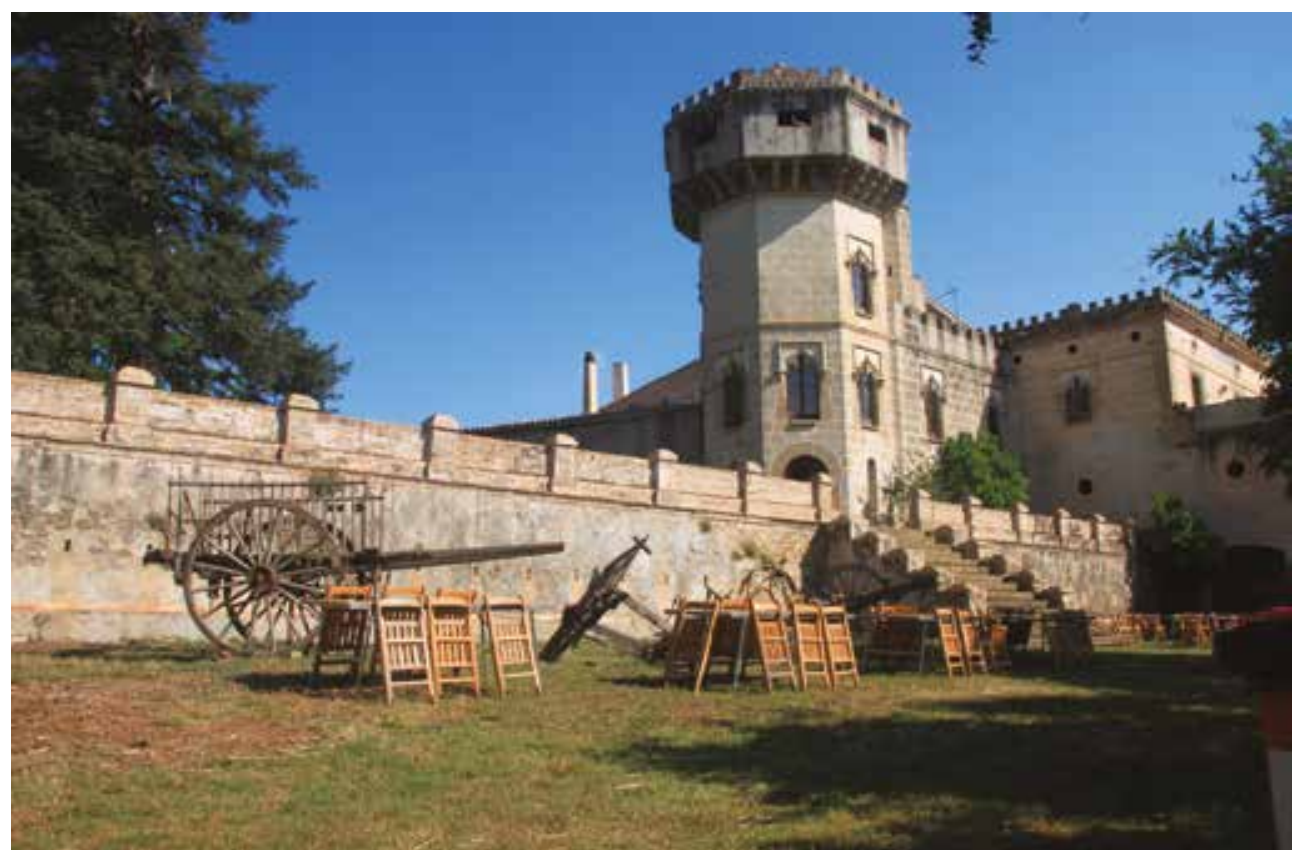

Figure 5. Las Heras, Medieval Festival.

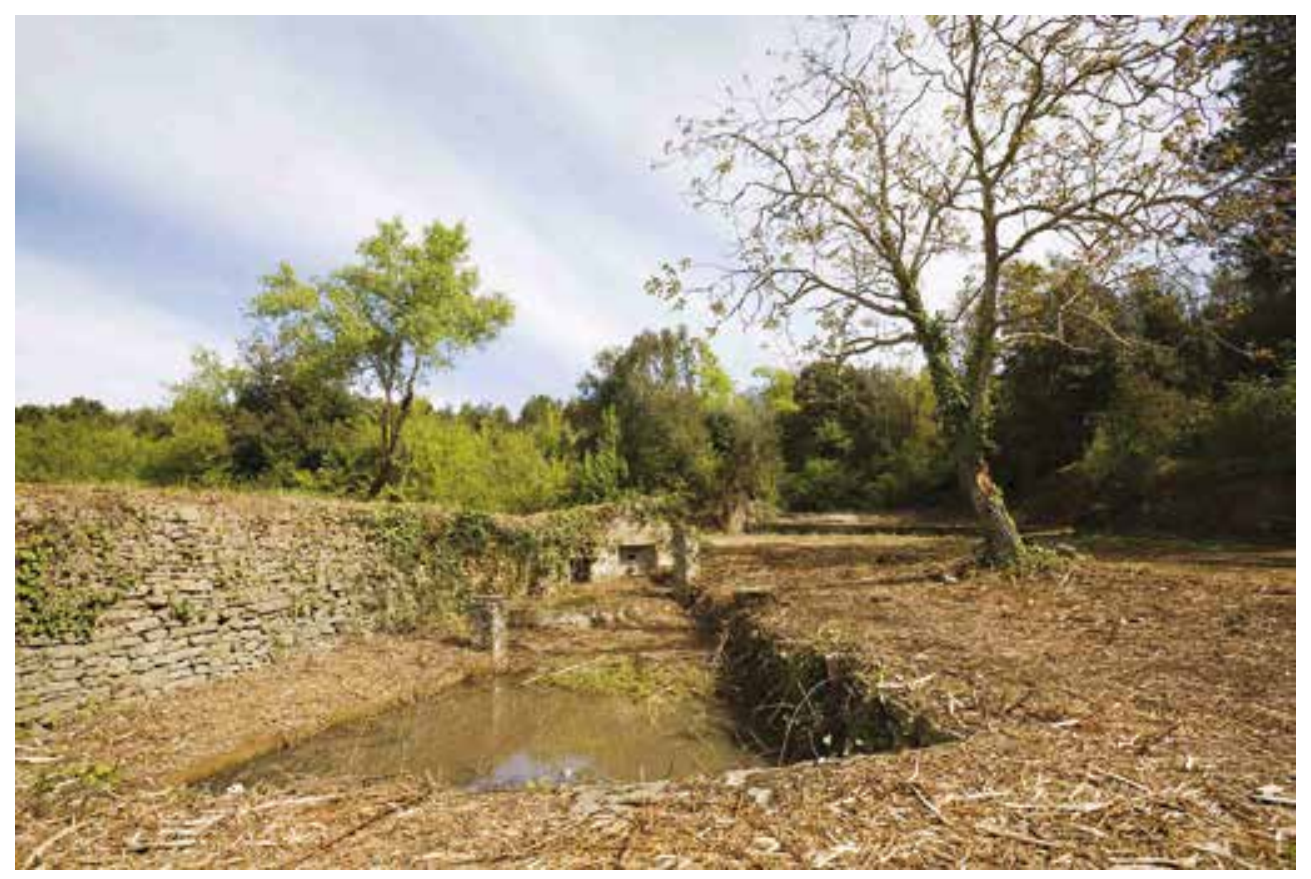

Figure 6. Las Heras, pool.

\section{Living history}

The Heras family name will die out with the current generation. But the story of the Heras de Adri house will remain alive. In 2008, the estate was bought by Alexander Kurt Engelhorn with the intention 
of returning the house and the neighbouring farmhouses to their original splendour. He was also determined to use the land for farming again.

Stone by stone, the walls are once again being built, the damaged elements are being reinforced and flooring, thresholds and window frames are being renovated. Paths that were once hidden by the vegetation are being re-opened. Seeds are being planted. It is a slow, manual process as befits a property that is a thousand years old.

Alexander Kurt Engelhorn aims to restore Can Heras and its surrounding farmhouses (Can Bailo, Can Pustis, Can Manel and Can Blanc) to their original condition. When it comes to the main house, more recent add-ons must be removed and some ruined elements must be rebuilt. But of the smaller farmhouses, only a few stones are left: they had been engulfed by the forest. There were even trees growing inside them. The stones are scattered all around. If there is a corner left standing, that corner will be taken down and re-built. The stones will be laid in exactly the same

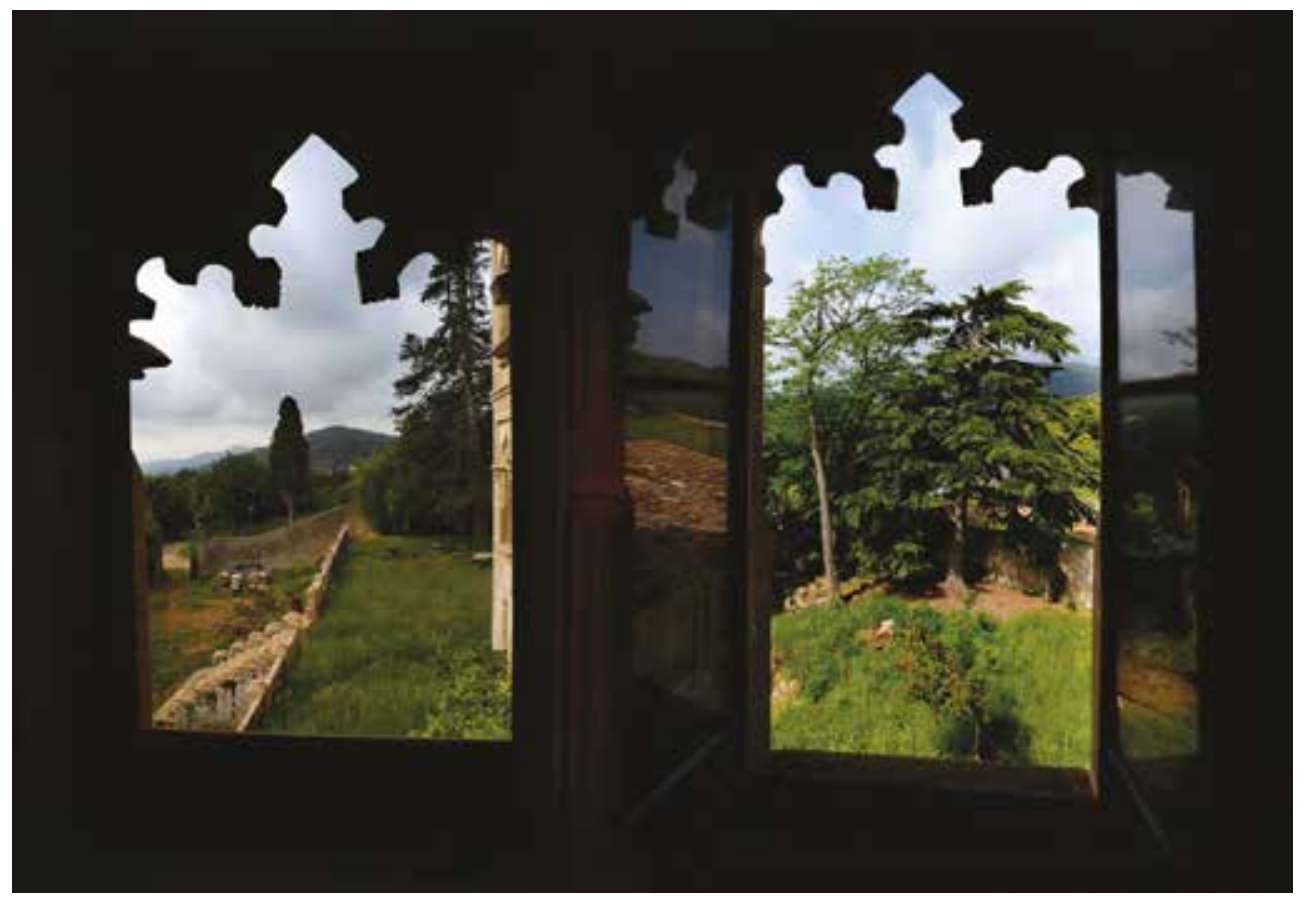

Figure 7. Las Heras, windows.

position they were in. This job can only be done by hand, with the utmost respect to the legacy left by earlier generations. This way of working is a perfect example of Alexander Kurt Engelhorn's outlook on life: "If I can't do something extraordinary, l'd prefer to do nothing at all." (J.J. Caballero ${ }^{1}$ ) 
Doing nothing is an idea that is usually associated with eastern religions, although not exclusively. Cedric Price gave me many bits of advice amongst which was "never take a decision until you have to." I think it true that as one gets older decisions are harder because you know more about the potential disaster of making a choice. By doing nothing, sometimes the need to act disappears anyway. What I find important in Las Heras is making no definite plan. Parts of our world are destroyed by masterplans.

The key word is evolution in a natural way that avoids preconception. After some thought and discussion it was decided to make an educational programme, which would allow students to visit and make additions to the land. The house would provide a place of retreat and sustenance, the land a canvas of possibility. The world of architectural education is confused and needs a place for students to escape to help free them from a zone of attempts to educate them.

I have to indulge hereinto my own reflection on the state of education. I find generally a huge ignorance about architecture and history in particular. Architecture today is a reflection on the current condition of success being based on notoriety and no depth of connection. We are not here by accident and I think it is important to try, even in vain, to understand the world that made you what you are and might become. I have often asked architects, and students, if they have ever had an architectural experience. Most look mystified! I admit that these occasions are quite rare, but are important to connect the architect to a sensation without intellectual filter. The chapel, by the architect monk Van de Lum in Holland was one of these experiences for me. The space, light and volume immediately touch you and you know all is well. This experience is not something you can teach. One can only hope!

There is no correct age at which to qualify although a number of regulatory bodies think there must be. This attitude does little more than produce "CAD fodder" for the increasing number of large commercial offices. These students have an architectural qualification but they are not architects. I am looking for someone that has soul. These true potential architects are quite rare, but are not as uncommon as we might think. I do know that they are not produced out of the masterclass system, where well known figures teach a number of students to become and produce work just like themselves; flattering, but not useful to the student. Some institutions organise themselves into "units," with Unit Masters. Generally these people are relatively young, because that is less expensive, and are looking for a celebrity status, which I understand but should be avoided. The projects set reflect the search that the Unit Masters are exploring and the work done by the students is the Unit Master's thinking and not the aspiring young architect. Of course a few (the best ones) revolt and maybe praised or rejected. It's a risk of life! 


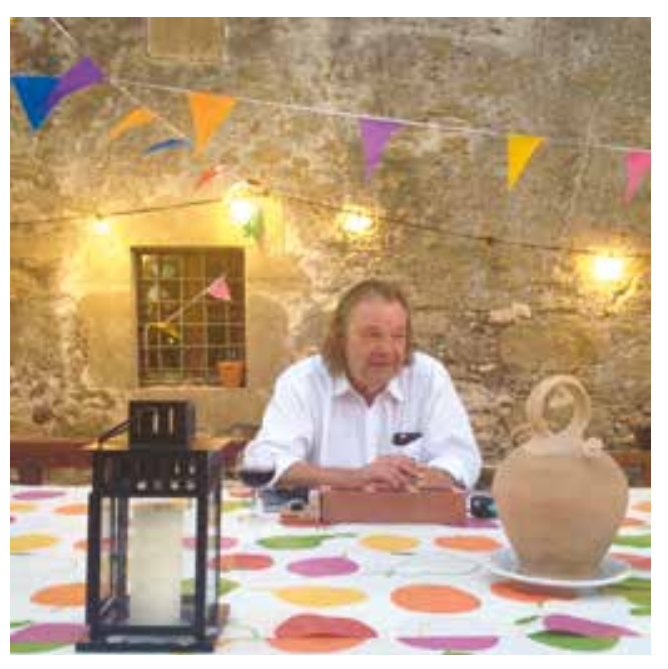

Figure 8. Will Alsop at Las Heras, August 23, 2016.

\section{HOW TO TEACH? NO MANIFESTOS!}

Las Heras has, in my mind, an important contribution to make which might go towards answering the question. There was initially the automatic response to a large tract of land occupied by one dominant house and five ruins and that was to do a masterplan to try and pull some vision of a possible future out of a chaos that appeared to reign. I was charged by the person who had bought it to tell him why he had bought it. This was my challenge. Many would see this as some luxury retreat for the rich and you could do that. My client is more interesting than that.

Masterplans are dangerous. They have become over the last three

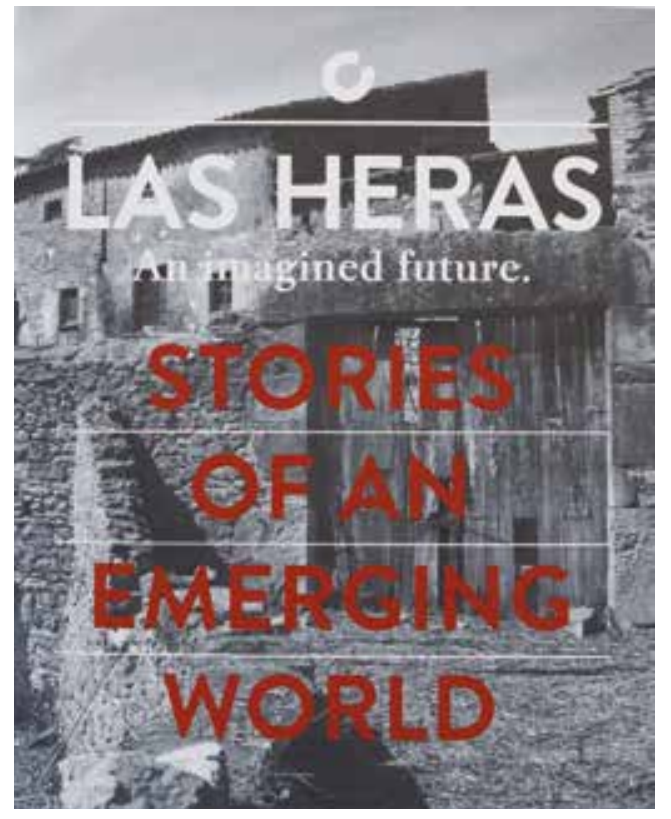

Figure 9. Will Alsop, with J.J. Caballero, Las Heras: An Imagined Future, ed. Nancy Alsop, London: John Rule 2014. Book cover. 
decades a piece of work that is rarely realised. They tend to be political and marketing devices that are often so banal that the more mindless they are, the more they are applauded. If they contain any ideas, those jewels of possibility are edited out to avoid any debate or discussion. On sizeable projects this process is carried out by committees of everincreasing size. For example the masterplan for the London Olympics has resulted in a public place (a park of some quality) which has to be approached via a huge shopping complex! This is not an idea of any worth and is certainly not beautiful. The more I consider the future of said futility the more I arrive at the concept of "evolution" and never taking decisions before you have to.

At Las Heras there is already an accumulation of stories. The facts are called history and the tales are myths. All contribute to the ambiance of the place. Even without knowing any of these the visitor is already attuned to their existence, even to the point of making up their own fictions as they wander through the buildings and the land. This is, I believe, true of any place in the world and it is the memories of the place that is as easily destroyed by the masterplan.

This thinking has led me to consider the concept of never knocking down any buildings because by doing so you destroy memories and stories. Instead it is possible to extend, build over, repair and add to the existing. This is an evolutionary approach that if adopted would lead to a diversity of experience; physically, visually and psychologically within our towns and cities that will preserve our heritage and sanity. It also challenges that other word which leads to boredom - context.

It was necessary at Las Heras to give an idea of change without planning it. For this reason I decided to write a short novel which would describe a possible future without determining it. Words are more open than drawings and plans and allow other people to invent in their imagination. The book is now published, entitled: Las Heras - Stories of an Emerging World (Fig. 9).

The book evolved beyond the novel into a history plus a number of appendices. The latter ones catalogue the flora \& fauna and also include a recipe book of dishes that can be created from ingredients that can be found on the land. It is, I hope, a "useful" book and is intended as a companion to the visitor.

To start the process of evolution, beyond some essential repairs, we decided to initiate an education programme open to all schools of architecture in the world. For those that wish to participate we provide accommodation, in a dormitory, food and wine, all for a modest fee. The students are asked to explore the terrain and find a place where they wish to construct an edifice that is capable of being slept in and that will last at least five years. It should be constructed of materials 
that can be found on the site although not exclusively. We can accept up to twelve students for a week, Work stops at 8pm daily - showers taken followed by supper and entertainment. In our experience the group working together find things out. Apart from "fun," which is a prerequisite of all activities, their perception of the term luxury is challenged.

\section{TIME IS FINITE}

It is true that apart from the mattresses, the comforts are basic, but a combination of working (together), making and laughter is a rare convergence and that is the essence of luxury.

Style is all too often confused with "taste" ("good taste!"). Lashings of taupe, marble and extremely expensive taps are the product of marketing, industry, mass production and magazine promotion. None of these things have anything to do with "style."

Style prevents good architects and designers to evolve. For example David Chipperfield is a good architect but is trapped by the architecture he is producing. If he changed to a more exploratory mode he would lose some of his customers. Patrick Heron, the painter, was trapped into stripes for decades, subtly changing from hard edge to soft. There was a market for his work, but in his eighties he became free and in the final decade of his life produced some of the most beautiful, interesting and intriguing works. The idea of style is pernicious and is essentially a lazy, but convenient way of proceeding. It is our intention at Las Heras to free visitors from a sense of what should be done, to one of discovery. Invention and joy are the two highest priorities. By working in small groups no one person is allowed to retreat into their own form of expression. When I used to teach sculpture at the St Martin's School of Art in London, the biggest problem we had with students was that they thought they were already artists and they had a preconception of what an artist was and how an artist behaves. Drinking too much and out of the studio fitted in this self-image. By creating a course based on points for attendance and group working which allowed time to observe others working we had some success. In reality only ever $10 \%$ would become artists, which is, in my view, an achievement. Las Heras works in a similar fashion. It is not "my" work but "our" work and therefore turns out to be a surprise for all. In this way I feel it makes a significant contribution to architectural education. There is a lot of building about! Not much architecture.

Following page: poems written by students at Las Heras.

Text continues at p. 14. - Ed. 
Poems by founding students of the London School of Architecture, during their residency at Las Heras, Summer 2016

\section{We Have Been Weaving}

We have been weaving.

Bending, folding, reaching, crouching,

Ducking, dropping, eating, sleeping,

Cutting, sawing, breaking, swearing.

In and out of winding roots,

See small wonky windows to other

Worlds.

There are 100 ways to fix

A to $B$,

[Everything is woven]

We have been weaving

(By Milly Salisbury, Las Heras, July 2016.)

\section{Morning Greetings}

Morning greetings, morning meetings, morning eating

Bamboo fetching, structure testing, sun resting

Form making, water sating

Tree chopping, mosquito swatting,

Nest weaving,

Don't want to be leaving

(By Maeve Dolan, Las Heras, July 2016.)

\section{Die Gedanken sind frei}

1. Die Gedanken sind frei, wer kann sie erraten, sie fliegen vorbei wie nächtliche Schatten.

Kein Mensch kann sie wissen, kein Jäger erschießen es bleibe dabei: Die Gedanken sind frei!

(Aus dem deutschen Lied)

2. Ich liebe den Wein, meine Freunde vor allen, sie tun mir allein am besten gefallen. Ich bin nicht alleine, bei meinem Glas Weine meine Freunde dabei: Die Gedanken sind frei!

\section{Thoughts are Free}

1. Thoughts are free, who can guess them, They fly past like night shadows.

No one can know them, no hunter can shoot them Keep it: the thoughts are free!

(From the German song)

2. I love the wine, my friends before all, They do me the best.

I'm not alone with my glass of wine My friends: The thoughts are free!

(By Timm Lindstedt, Las Heras, July 2016.) 


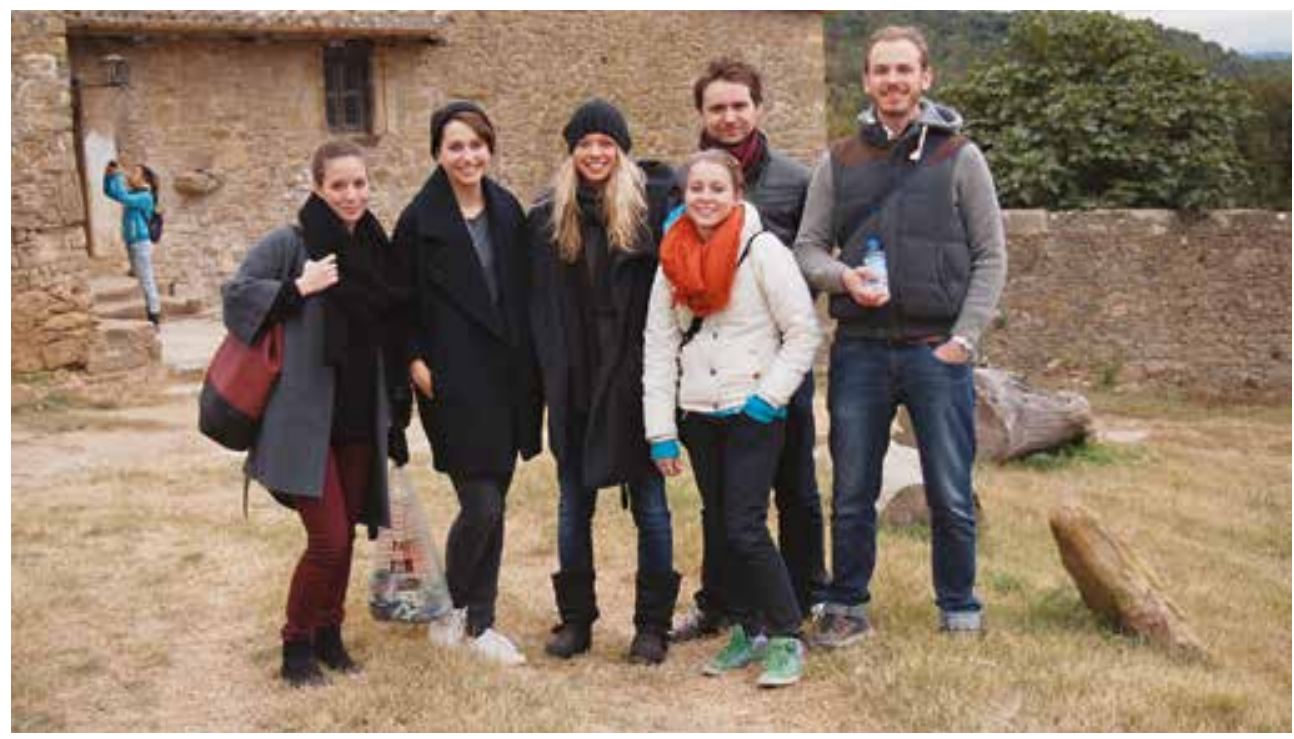

Figure 10. Las Heras, students from the Technische Universität, Vienna, summer 2016.

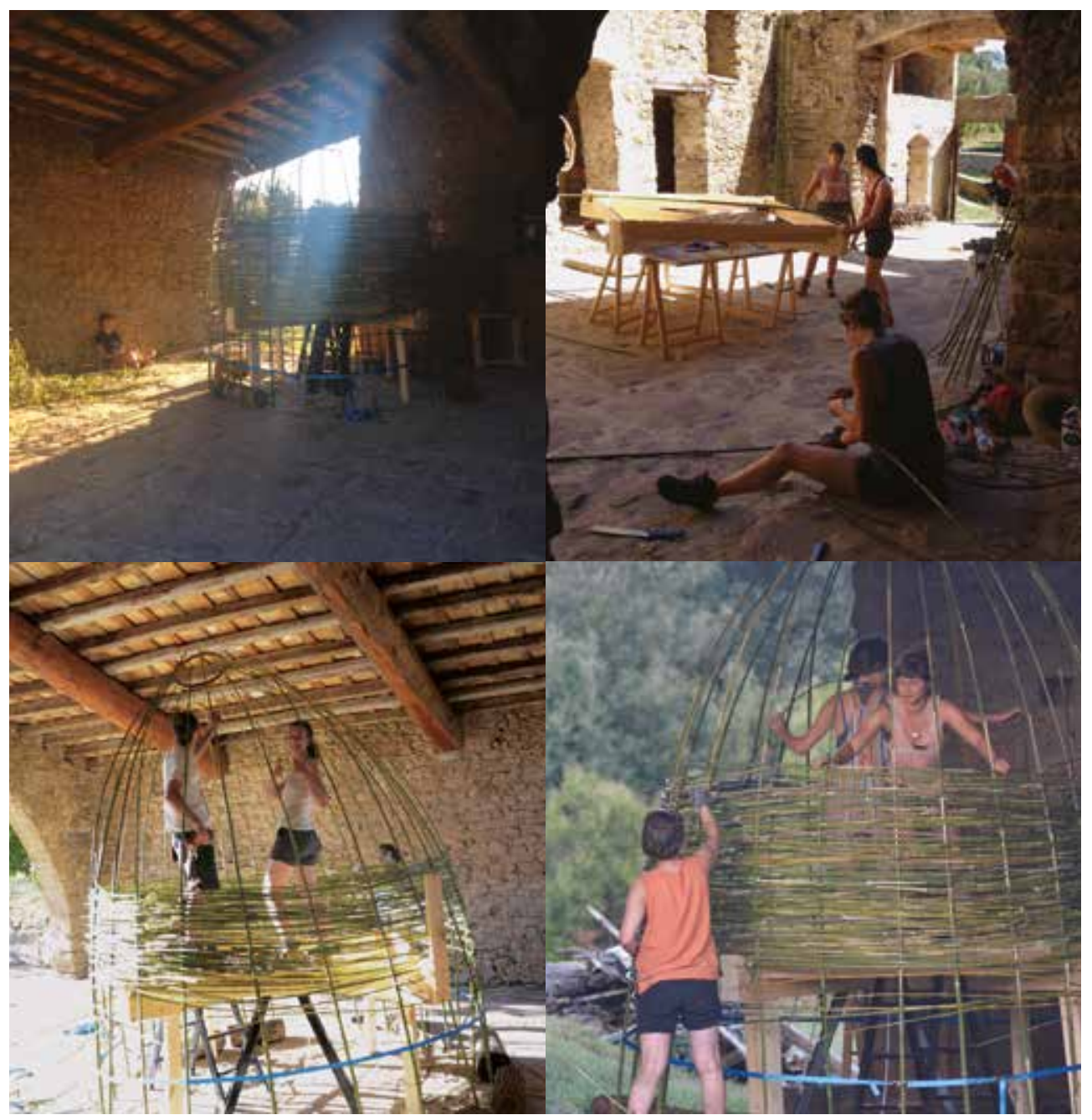

Figure 11. Las Heras, students from the London School of Architecture, summer 2016. 
At Las Heras we have a carpentry workshop and soon ceramics and a blacksmith. To get one's hands dirty is part of the act of discovery. To understand the difficulties of making a timber joint is a part of understanding how the built world comes into existence. Gardening is allowed. To experience what you build, to perhaps make love in the discovered edifice is an important part of the whole experience. Architecture is a strange art as during the education process everything is communicated through drawings, paintings, films, models and words. All are some approximation of an imagined future. Unlike art, when you stop working on it, it is finished. At least until the next day when you might decide to do more - or stop. Architecture is never, or rarely resolved because it is too expensive and, particularly today, too risky. The student and teacher are usually denied the actual experience. Ultimately space can only be a phenomenon to be felt. The Las Heras land is intended to help in this regard.

There are many huge issues to be dealt with within architecture. Climate Responsibility, Social Impact, Beauty, Health \& Safety, Digital Banality Etc. Etc. but in reality many of them are not seen to be the direct responsibility and it is certainly true that very often clients do not wish their architects to think too deeply about these issues as there are often cost implications. We must remember we can always say no!!! I do understand that in the near future, much of our work can be executed by computer programmes directly linked to automated systems in factories, but in this case society has to decide if the product is good and whether or not it solves the problems that exist. These systems will provide building and shelter, but will it be good enough?

Architects worship the new - quite rightly - but sometimes at the expense of their own self-worth. They were amongst the first to recognise the idea of pre-fabrication and miniaturisation to solve the housing crisis that we find in many countries today. The micro flat often smaller than a caravan, but no advantage of having wheels (snail syndrome) is a solution. More technology packing in less and less space. Space is the great luxury and too little space results in bad behaviour. By reducing the home to affordable product raises many questions beyond the social acceptability. If it proved popular, and it might, out of desperation, it would start to be manufactured by large industry. Similar to a car product, the variations, with the exception of price, will be negligible and certainly would not require the skills of an architect. I am not sure that globalisation is either good for the environment or society. The production of homes has nothing to do with architecture. The act of making a home, or feeling at home, is a part of architecture. I think to be able to build what you like, wherever you like is important. The act of making creates within itself a sense of place. It might not involve architects either, but traditionally the architect did not concern 


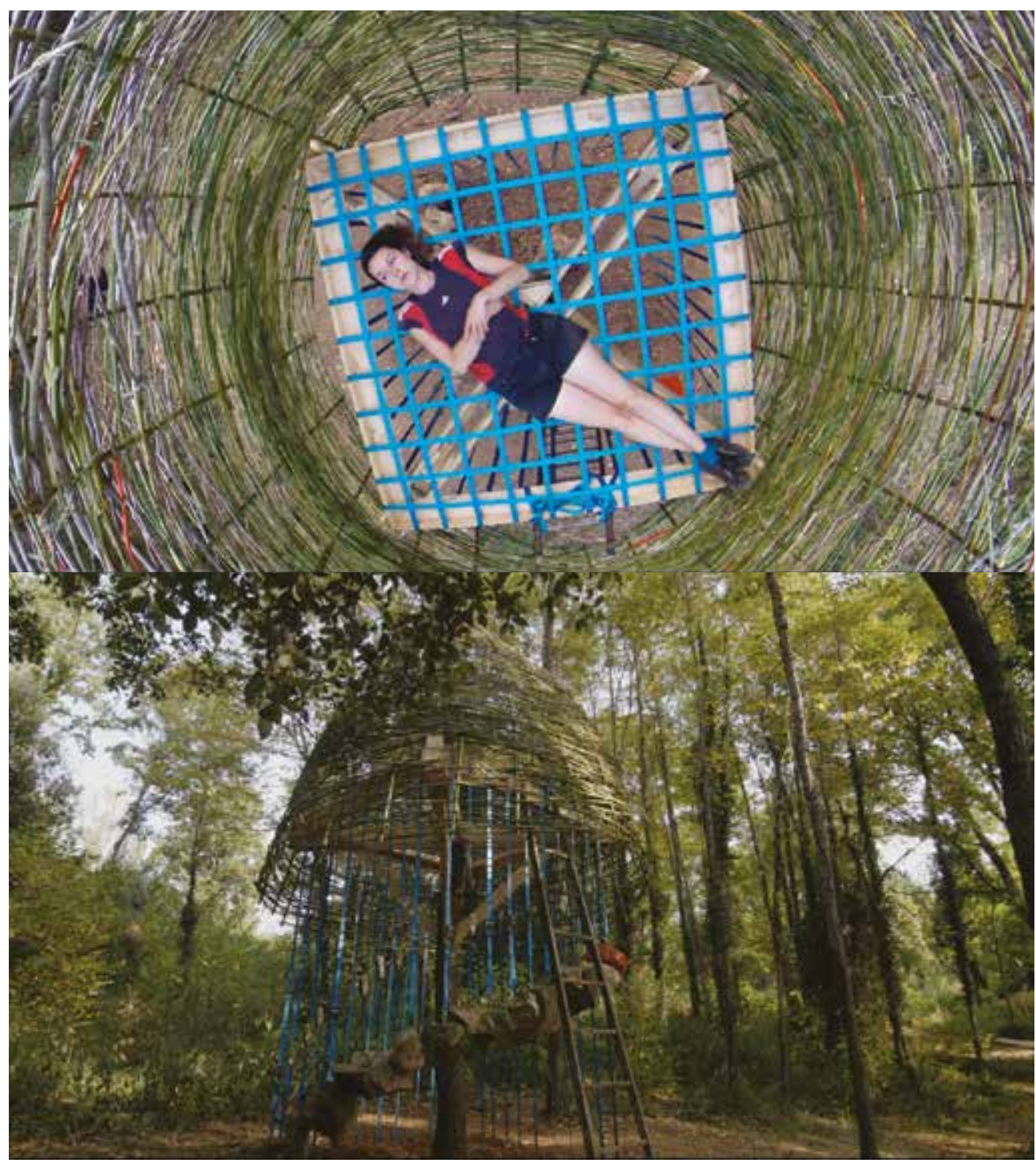

Figure 12. Stills from the film Las Heras, by Savage Mills: http://www.all-worldwide.com/how/ movies/.

themselves with housing but only the individual house and civic buildings. Now there are too many architects to be sustained by such a reduction in workload.

So what?

Las Heras is a perfect place to make and take ownership. It is beyond architectural criticism. Criticism by its very nature is comparative and as such must divide the work into various factions in order to make a judgement. This necessity leads to an ossification of styles and methods which actively leads nowhere. I find it strange that in art the curator has become the artist and the artists are merely the medium through which they try and establish their own importance. In architecture the journalist has become critic and the critic an historian, which of course is a form 
of status inflation, which allows non architects to become more involved in decision making than the architect. The architect and the artist are demoted to a medium that allows others to speak. At Las Heras no-one decides - it happens!

I have no doubt that robots will make many architects redundant in the very near future. It is a death of one of the arts and sciences which no doubt will be regretted and mourned. Obviously, robotics will not only create redundancies in architects but also many other sectors of work. Good news for venture capitalists with fewer troublesome staff to worry about, but also maybe good news for society. At last a release from drudgery and tediousness. I have never really understood why workers would strike for the "right to work." Maybe in future the "right not to work" will be the cry. Society must prepare itself for this new condition. I assume that the number of people will rise, unless mass genocide is an option, which it is not. To live without work, in the traditional sense, will require a very new approach to living; needing money, education, wisdom and spirit of useful disobedience. Las Heras is such a place that might exist to allow a discovery of peace, responsibility, farming and an air of contentment. All these things will be necessary.

Come \& explore!

\section{Awards}

This essay was awarded Honorable Mention at the 2015 THE PLAN Best Paper Award contest. - Ed. 


\section{Notes}

1. J.J. Caballero, "Witness to history," in Will Alsop, with J.J. Caballero, Las Heras: An Imagined Future, ed. Nancy Alsop, London: John Rule 2014.

\section{Credits}

\section{Kurt Engelhorn}

Extracts from the book: Alsop, Las Heras: Stories of an Emerging World, 2014.

Historical account: JJ Caballero

Poems: students of the London School of Architecture

Images: students of LSA and TU Vienna; Savage Mills; Will Alsop; aLL Design

Sketches: Will Alsop

Illustrations: (within the book): Abi Daker

Book design: aLL Design

\section{More on Las Heras}

Film by Savage Mills: http://www.all-worldwide.com/how/movies/

To visit Las Heras with a group of students, please contact:

Daisy Froud or Sophie Smith

c/o aLL Design 1-5 Vyner Street, London E2 9DG

Tel: +44(0)20 70950516

E-mail: lasheras@all-worldwide.com; d.froud@all-worldwide.com s.smith@all-worldwide.com

Twitter: @aLL_lasheras

Instagram: all_lasheras

Facebook: https://www.facebook.com/profile.php?id=100009745592316

LAS HERAS website: http://www.masdelasheras.com/

ALL DESIGN website: http://www.all-worldwide.com/what/master-planning/las-heras/

Will Alsop, OBE, RA, is a prominent architect and artist, and Director of "aLL Design," which he established in 2011. He was awarded the RIBA Stirling Prize for Peckham Library, London and the first RIBA World Award for The Sharp Centre for Design (OCADU), Toronto, amongst numerous accolades for a multitude of projects. His core values are innovation and expression with an emphasis on enjoyment - his practice is founded principally to "make life better."

He sits on architectural advisory boards for Wandsworth and Kensington \& Chelsea Councils and is Professor at the Technische Universität, Vienna, and Professor of Architecture at the School of Architecture, University for the Creative Arts - Canterbury, UK. E-mail: info.london@all-worldwide.com - www.all-worldwide.com - @AllDesign1, @walsop 